\title{
Edutainment Model Implementation Using If History in History Learning (Classroom Action Research at X MIPA 4 SMAN 6 Bandung)
}

\author{
Fahmi Nur Ramadhan \\ Universitas Sebelas Maret \\ fahminr11@gmail.com
}

Article History

accepted 1/09/2020

approved 4/10/2020

published 1/12/2020

\begin{abstract}
This research were taken based on the low of students' understanding in historical comprehension class. The low students' understanding about history can be seen from the tendency of students that depend on textbooks that make them them cannot develop historical facts more broadly. This research tries to answer some formulation of the problem including how teachers application the learning methods to improve students' understanding of history through edutainment models using if history. The research method used in this research is the Class Action Research method with the research design model Kemmis and McTaggart that consist of the stages of planning, action, observation, and reflection. Based on the results of the research that have been done in three actions, it shows an increase in the understanding of students' history after the application of edutainment models using if history. In action I the writer obtained a score of $41.6 \%$, action II amounted to $55.5 \%$, in action III and IV of $100 \%$. This increase shows that the application of edutainment models using if history is very effective to improve students' historical understanding in history learning.
\end{abstract}

Keywords: Edutainment model, historical comprehension, If History

\begin{abstract}
Abstrak
Penelitian ini dilatarbelakangi oleh rendahnya pemahaman kesejarahan (historical comprehension) siswa dalam pembelajaran sejarah di kelas. Rendahnya pemahaman kesejarahan siswa tersebut dapat terlihat dari kecenderungan siswa yang terfokus pada buku teks sehingga mereka tidak dapat mengembangkan fakta-fakta sejarah yang ada secara lebih luas. Penelitian ini mencoba untuk menjawab rumusan masalah diantaranya adalah bagaimana penerapan pembelajaran untuk meningkatkan pemahaman kesejarahan siswa melalui model edutainment menggunakan if history. Metode penelitian yang digunakan adalah metode Penelitian Tindakan Kelas dengan desain penelitian model Kemmis dan McTaggart yang terdiri dari tahap perencanaan, tindakan, observasi, dan refleksi. Berdasarkan hasil penelitian yang telah dilakukan menunjukkan adanya peningkatan pemahaman kesejarahan siswa setelah diterapkannya model edutainment menggunakan if history. Pada tindakan I diperoleh skor sebesar $41,6 \%$, tindakan II sebesar $55,5 \%$, pada tindakan III dan IV sebesar $100 \%$. Peningkatan tersebut menunjukkan bahwa penerapan model edutainment menggunakan if history sangat efektif untuk meningkatkan pemahaman kesejarahan siswa dalam pembelajaran sejarah.
\end{abstract}

Kata Kunci: Model edutainment, historical comprehension, If History

Social, Humanities, and Education Studies (SHEs): Conference Series https://jurnal.uns.ac.id/shes

p-ISSN 2620-9284

e-ISSN 2620-9292

This work is licensed under a Creative Commons Attribution-ShareAlike 4.0

International License. 


\section{PENDAHULUAN}

Pembelajaran sejarah merupakan suatu ilmu yang tidak dapat di pandang remeh, karena melalui ilmu sejarahlah generasi baru dapat belajar dan melakukan perkembangan dengan memahami berbagai macam kejadian masa lalu. Dewasa ini pembelajaran sejarah sudah menginjak langkah yang cukup inovatif dengan diperkenalkannya kurikulum 2013 yang dimana pembelajaran menekankan kepada siswa sebagai subjek utama dalam kegiatan belajar dan mengajar, pembelajaran sejarah tidak lagi harus berpacu kepada guru sebagai orientasi utama dalam pembelajaran, akan tetapi bagaimana guru menjadikan siswa itu sebagai fokus utama dalam kegiatan belajar. Meskipun demikian, sayangnya pada saat ini pembelajaran masih saja bersifat konvensional, yang dimana siswa bertumpu pada textbook dalam mencoba memahami sejarah.

Hal tersebut terjadi di kelas X MIPA 4 SMA Negeri 6 Bandung, para siswa di kelas tersebut terlalu saja mengandalkan sumber textbook dan internetsebagai sumber utama dalam belajar, tanpa memahami esensi dari pembelajaran sejarah itu sendiri sehingga nilai dari historical comprehension (pemahaman sejarah) siswa sangatlah

kurang. Tidak hanya itu saja, pembelajaran sejarah yang kurang variatif juga menyebabkan siswa merasa sangat bosan dalam pembelajaran sejarah, sehingga ketika siswa belajar sejarah mereka cenderung tidak kritis dalam memahami suatu peristiwa sejarah. Oleh karena itu, dibutuhkan suatu model belajar baru yang dapat memicu pemahaman siswa tentang pembelajaran sejarah, tentu saja agar siswa dapat memahami sejarah, guru harus memberikan suatu stimulus yang dapat membuat siswa tidak hanya memahami akan tetapi membuat pelajaran lebih interaktif, aktif dan menarik.

Berdasarkan permasalahan yang telah dipaparkan di atas, terdapat suatu model yang dapat meningkatkan pemahaman kesejarahan (historical comprehension) siswa dan dapat menghilangkan pandangan 'membosankan' dalam pembelajaran sejarah. Model tersebut adalah model Edutainment. Menurut Sutrisno (dalam Hamid, 2013, hlm. 17) edutainment berasal dari kata education dan entertainment. Education berarti pendidikan, sedangkan entertainment adalah pendidikan yang menghibur atau menyenangkan. Sementara itu, dari segi terminologi, edutainment adalah suatu proses pembelajaran yang didesain sedemikian rupa, sehingga muatan pendidikan dan hiburan bisa dikombinasikan secara harmonis untuk menciptakan pembelajaran yang menyenangkan. Dalam hal ini, pembelajaran yang menyenangkan biasanya dilakukan dengan humor, permainan (game), bermain peran (role play), dan demonstrasi. Pembelajaran juga dapat dilakukan dengan cara-cara lain, asalkan siswa dapat menjalani proses pembelajaran dengan senang. Sedangkan menurut Hamid (2013, hlm. 19-20) sendiri, dapat disimpulkan bahwa edutainment adalah suatu cara untuk membuat proses pendidikan dan pengajaran bisa menjadi begitu menyenangkan, sehingga para siswa dapat dengan mudah menangkap esensi dari pembelajaran itu sendiri, tanpa merasa bahwa mereka tengah belajar.

Dengan memanfaatkan model pembelajaran edutainment diharapkan siswa di kelas X MIPA 4 dapat memiliki pemahaman dalam memahami sejarah dengan baik karena kemampuan historical comprehension merupakan salah satu standar dari standar kemampuan historical thinking (berpikir kesejarahan). Mengembangkan historical comprehension di sekolah diharapkan menjadi kemampuan awal yang dimiliki sebelum memiliki kemampuan berpikir sejarah lainnya. Historical comprehension 
merupakan aspek penting dalam pembelajaran sejarah, karena jika siswa sudah memahami materi sejarah yang diajarkan maka siswa tersebut mampu mengerti maknanya serta mengerti konsepnya. Selain mengerti makna yang terkandung dalam materi sejarah, siswa juga dapat mengembangkan keterampilan sejarahnya secara mendalam serta dapat mengimplementasikannya (Kumalasari, 2016, hlm. 15).

Berdasarkan pemaparan di atas, peneliti mengambil pokok permasalahan yakni "Bagaimana upaya untuk meningkatkan kemampuan pemahaman kesejarah siswa melalui model edutainment menggunakan if history'. Penelitian ini bertujuan untuk meningkatkan pemahaman kesejarah siswa dalam pembelajaran sejarah. Selain itu penelitian ini memiliki manfaat secara teoritis dan praktis, yaitu diharapkan dari penelitian yang dilakukan dapat memberikan kontribusi bagi ilmu pengetahuan sejarah, khususnya dalam hal penggunaan model edutainment dalam pembelajaran sejarah untuk meningkatkan pemahaman kesejarahan siswa dan diharapkan dari penelitian yang dilakukan dapat memberikan kontribusi bagi tenaga pengajar yang membaca tulisan ini untuk dapat menggunakan model edutainment dalam proses pembelajarannya sehingga terwujud variasi dalam pembelajaran sejarah.

\section{METODE}

Metode penelitian yang digunakan adalah PTK (penelitian tindakan kelas) atau action research. Pada buku Konstruksi Pembelajaran Sejarah Kritis (Supriatna, 2007, hlm. 190) menjelaskan bahwa Penelitian tindakan kelas (PTK) merupakan salah satu jenis penelitian pendidikan yang dapat digunakan oleh guru sejarah untuk meningkatkan kualitas pembelajaran di kelas. Permasalahan pembelajaran sejarah seperti minat siswa yang rendah, nilai sejarah yang menurun, rendahnya perhatian siswa terhadap cara guru mengajar, kelangkaan sumber, dan lain-lain dapat diketahui penyebabnya melalui PTK. Produk akhir dari PTK adalah selain memecahkan masalah juga menghasilkan sebuah model atau prosedur yang paling cocok serta relevan dengan pengalaman guru, cara siswa belajar serta budaya belajar yang ada pada lingkungan setempat.

Desain yang dilakukan dalam penelitian ini adalah tipe yang di desain oleh Kemmis dan McTaggart. Pada sebuah siklus terdapat beberapa tahapan yakni perencanaan (plan), tindakan (act), pengamatan (observe) dan refleksi (reflect). Dalam model Kemmis dan McTaggart sendiri hanya terdapat satu tindakan dalam satu siklus. Lazimnya dalam penelitian tindakan kelas, penelitian ini pun akan melalui beberapa siklus. Hal ini dimaksudkan supaya kekurangan-kekurangan pada siklus sebelumnya dapat diperbaiki, sehingga pada siklus berikutnya terjadi perbaikan dalam proses pembelajaran dengan makin mendekati kepada kondisi ideal hingga akhirnya tercapai tujuan dari penelitian.

Fokus dari penelitian ini adalah perpaduan antara model edutainment dengan If History yang dimana memiliki langkah-langkah pelajaran sebagai berikut:

Tabel 1. Langkah-Langkah Pembelajaran Model Edutainment Model Edutainment dengan menggunakan If History Guru Siswa

\begin{tabular}{lrllr}
\hline \multicolumn{4}{c}{ Model Edutainment dengan menggunakan If History } \\
Guru & \multicolumn{2}{c}{ Siswa } \\
\hline Guru menyampaikan materi sejarah & Siswa memperhatikan sekaligus \\
yang akan diajarkan. Siswa diajak & menyimak materi sejarah yang \\
untuk & dapat & merasakan, disampaikan. & \\
\hline
\end{tabular}




\begin{tabular}{|c|c|}
\hline $\begin{array}{l}\text { membayangkan, } \\
\text { mengimajinasikan jika dirinya sedang } \\
\text { terlibat pada sebuah peristiwa sejarah. }\end{array}$ & \\
\hline $\begin{array}{l}\text { Guru memberikan kesempatan } \\
\text { kepada siswa untuk bertanya atau } \\
\text { mengungkapkan apa yang siswa ingin } \\
\text { ketahui dari hasil pengamatan siswa } \\
\text { mengenai narasi sejarah yang telah } \\
\text { disampaikan. }\end{array}$ & $\begin{array}{l}\text { Siswa bertanya dan mengeksplorasi } \\
\text { lebih jauh lagi tentang narasi sejarah } \\
\text { yang telah disampaikan dan diamati. }\end{array}$ \\
\hline $\begin{array}{l}\text { Guru membagi siswa ke dalam } 4 \\
\text { kelompok. Kemudian, guru meminta } \\
\text { siswa untuk membuat atau menuliskan } \\
\text { materi yang akan dan telah dibahas } \\
\text { sebelumnya dengan tulisan berupa } \\
\text { cerita sejarah dengan bahasa mereka } \\
\text { sendiri. Nantinya, pada siklus ke-III, } \\
\text { cerita sejarah tersebut dituangkan ke } \\
\text { dalam bentuk scrapbook. Pembuatan } \\
\text { cerita sejarah sendiri tidak lepas dari } \\
\text { sumber sejarah atau fakta-fakta yang } \\
\text { mendukung. }\end{array}$ & $\begin{array}{l}\text { Siswa berkumpul dan mulai membuat } \\
\text { cerita sejarah tanpa terlepas dari } \\
\text { sumber-sumber belajar berupa buku } \\
\text { teks dan sumber-sumber sejarah } \\
\text { lainnya yang relevan. Isi dari cerita } \\
\text { sejarah itu sendiri menggambarkan } \\
\text { bagaimana siswa merasakan jika } \\
\text { dirinya terlibat pada suatu peristiwa } \\
\text { sejarah dengan menggunakan } \\
\text { bahasanya sendiri. }\end{array}$ \\
\hline $\begin{array}{l}\text { Setelah cerita sejarah selesai dibuat, } \\
\text { guru meminta siswa untuk } \\
\text { membacakan cerita sejarah yang telah } \\
\text { dibuat secara berkelompok di depan } \\
\text { kelas oleh perwakilan dari setiap } \\
\text { kelompok. }\end{array}$ & $\begin{array}{l}\text { Siswa yang menjadi perwakilan } \\
\text { kelompok membacakan dan } \\
\text { menyampaikan cerita sejarah yang } \\
\text { telah dibuat secara berkelompok } \\
\text { menggunakan teknik vokal, ekspresi } \\
\text { baik dari wajah maupun gerak tubuh. }\end{array}$ \\
\hline
\end{tabular}

Sekolah yang dijadikan sebagai penelitian ini adalah SMA Negeri 6 Bandung. yang berlokasi di Jalan Pasirkaliki No. 51 Bandung, Kec. Cicendo, Kota Bandung Jawa Barat. Telp. (022) 6011309. Alasan peneliti memilih SMA Negeri 6 Bandung untuk dijadikan lokasi penelitian ialah karena SMA Negeri 6 Bandung ini merupakan tempat peneliti melakukan Program Pengalaman Lapangan. Selain itu, pihak sekolah mengijinkan penelitian dan guru mitra sangat mendukung peneliti untuk melaksanakan penelitian.

Subjek pada penelitian ini adalah siswa kelas X MIPA 4 semester ganjil tahun ajaran 2018 / 2019 yang berjumlah 36 siswa, terdiri dari 13 siswa laki-laki dan 23 siswa perempuan. Ada beberapa alasan penulis menggunakan subjek penelitian dikelas ini yaitu, pertama selama melakukan pra-penelitian penulis mengobservasi kegiatan belajar mengajar dikelas tersebut. Kedua, peneliti menemukan masalah penting pada kegiatan belajar mengajar untuk dipecahkan di kelas tersebut. Ketiga, penulis menggunakan metode penelitian tindakan kelas dalam memecahkan masalah dalam kelas tersebut.

Adapun instrument penelitian yang digunakan dalam penelitian kali ini adalah lembar observasi, catatan lapangan dan pedoman wawancara. Teknik pengumpulan yang dilakukan oleh peneliti adalah dengan menggunakan observasi, wawancara dan studi dokumentasi. Kemudian hasil penelitian ini diolah dan divalidasi dengan member check, triangulasi, audit trial dan expert opinion. 
HASIL DAN PEMBAHASAN

Penelitian ini memadukan model edutainment menggunakan if history yang dilakukan sebanyak 3 tindakan dimana setiap tindakan ini peneliti mengkolaborasikan model edutainment menggunakan if history dengan cerita sejarah. Pemahaman kesejarahan atau historical comprehension sendiri sangat penting untuk dikembangkan dalam pembelajaran sejarah bagi siswa. Hal ini dikarenakan bahwa historical comprehension memfokuskan pada keterampilan dalam kemampuan siswa untuk mengkritik informasi sejarah berdasarkan pengetahuannya, artinya siswa mampu menentukan kebenaran informasi yang didapatkan. Ketika siswa mampu mengkritik informasi sejarah tersebut maka siswa mampu menangkap makna yang terkandung di dalamnya untuk dijadikan sebuah nilai yang akan diterapkan untuk masa sekarang dan yang akan datang. Tentunya hal ini sesuai dengan pendapat Ismaun (2005: 244) tentang historical comprehension:

"memiliki pengetahuan dan pemahaman tentang peristiwa, memiliki kemampuan berpikir secara kritis yang dapat digunakan untuk menguji dan memanfaatkan pengetahuan sejarah, memiliki keterampilan sejarah yang dapat digunakan untuk mengkaji berbagai informasi yang sampai kepadanya guna menentukan kesahihan informasi tersebut; serta memahami dan mengkaji setiap perubahan yang terjadi dalam masyarakat di lingkungan sekitarnya serta digunakan dalam mengembangkan kemampuan berpikir kritis dan analitis."

Historical comprehension adalah kemampuan membaca, memahami hasil cerita sejarah dan menjelaskan peristiwa masa lalu melalui pengetahuan dan pengalaman yang dimilikinya, serta menghubungkan dengan kehidupan masa kini. National Center for History in the Schools dalam Setyorini (2018: 27).

Selanjutnya, peneliti kemudian mulai mendiskusikan tahap perencanaan model edutainment menggunakan if history untuk meningkatkan historical comprehension siswa di kelas X MIPA 4 bersama guru mitra tentunya dengan mempersiapkan segala hal yang mendukung proses pembelajaran seperti RPP, materi pembelajaran, media pembelajaran. Sesuai dengan kesepakatan antara peneliti dengan guru mitra pada bagian materi yang akan disampaikan dari tindakan I-IV ialah Masuk dan Berkembangnya Hindu Buddha di Indonesia. Perencanaan pada siklus I, II, dan III terdapat perbedaan dalam merencanakannya, hal ini dilakukan sebagai upaya memperbaiki hasil dari refleksi siklus sebelumnya.

Pada perencanaan pembelajaran menggunakan model edutainment sendiri, peneliti sebagai guru membagi kelas ke dalam 4 kelompok dengan masing-masing kelompok beranggotakan 9 orang siswa. Setelah pembagian kelompok selesai, tahap selanjutnya ialah membuat cerita sejarah yang sesuai dengan materi yang telah diajarkan sebagai contoh untuk siswa membuat cerita sejarah nantinya. Perlu diketahui, model pembelajaran edutainment ini bertujuan untuk menciptakan suasana pembelajaran yang menyenangkan, sesuai dengan pendapat Hidayanti dan Djumali $(2016: 13)$

"Tujuan dari metode ini agar siswa bisa mengikuti dan mengalami proses pembelajaran dalam suasana yang gembira, menyenangkan, menghibur, dan mencerdaskan."

Tahap perencanaan selanjutnya ialah membuat cerita sejarah yang akan dijadikan contoh dan ditampilkan pada saat pembelajaran sebelum siswa membuat cerita sejarah mereka sendiri. Peneliti mengumpulkan, membaca, dan menggunakan sumber-sumber buku sejarah yang terkait dengan cerita sejarah yang akan dibuat sesuai dengan materi yang akan diberikan. Peneliti juga harus menyiapkan bagaimana cara membaca cerita sejarah ini agar terlihat menarik bagi siswa. Tentunya pembuatan cerita 
sejarah ini bertujuan untuk dapat meningkatkan pemahaman kesejarahan siswa sesuai dengan Ma'mur (2008) yang berpendapat:

"Historical comprehension mencakup kemampuan untuk mendengar dan membaca cerita dan narasi sejarah dengan penuh pengertian, untuk mengidentifikasi elemen dasar dari suatu narasi sejarah dengan penuh pengertian, untuk mengidentifikasi elemen dasar dari suatu narasi atau struktur kisah, dan untuk mengembangkan kemampuan menggambarkan masa lalu berdasarkan pengalaman pelaku sejarah, literatur sejarah, seni, artefak, dan catatan-catatan sejarah dari masanya".

Perencanaan yang dibuat dari tindakan I hingga IV ini harus benar-benar dipersiapkan secara matang. Persiapan ini akan sangat berpengaruh bagi pembelajaran model edutainment itu sendiri. Perencanaan bagaimana jalannya model edutainment menggunakan if history yang dikolaborasikan dengan cerita sejarah harus benar-benar dapat membuat siswa tertarik untuk membuat cerita sejarah tersebut. Kesesuaian materi pun harus benar-benar diperhatikan, mengacu pada tindakan I hingga IV, materi harus disampaikan secara singkat, padat, namun bermakna. Tentunya hal ini agar edutainment sendiri dapat dilakukan dengan maksimal. Seperti yang disampaikan oleh Hamruni (dalam Pangastuti, 2014, hlm. 63) bahwa edutainment harus memperhatikan beberapa aspek, diantaranya menarik perhatian siswa dan menyajikan materi yang relevan. Pada saat pembelajaran pun harus diselingi dengan ice breaking agar siswa tetap merasakan pembelajaran yang menyenangkan dan tentunya tidak merasa jenuh akan pembelajaran. Hal ini sesuai dengan yang dikemukakan Fanani (2010:69) "Jika sentuhan aktivitas (ice breaking) ini diterapkan pada proses pembelajaran di kelas, maka besar kemungkinannya siswa kembali pada kondisi (semangat, motivasi, gairah belajar, kejemuan, dan lain sebagainya) yang lebih baik".

Tahap perencanaan selanjutnya ialah bagaimana siswa dapat memenuhi indikator pemahaman kesejarahan. Mengacu pada proses tindakan I hingga IV, peneliti harus mempersiapkan buku-buku juga memilih sumber-sumber internet yang dapat dipercaya yang nantinya dijadikan sumber oleh siswa dalam membuat cerita sejarah secara berkelompok selain sumber-sumber rujukan yang siswa dapatkan sendiri. Ini artinya bahwa pada penerapan model edutainment harus mempersiapkan hal-hal yang mendukung tujuan dari model edutainment itu sendiri.

Perencanaan tersebut dilakukan oleh peneliti dan diterapkan oleh peneliti dengan hasil sebagai berikut Berdasarkan hasil temuan dilapangan, yakni mengenai penerapan model edutainment untuk meningkatkan pemahaman kesejarahan siswa kelas X MIPA 4 SMA Negeri 6 Bandung yang mengalami peningkatan disetiap tindakannya. Berikut ini akan dipaparkan data hasil meningkatkan pemahaman kesejarahan siswa dalam pembelajaran sejarah melalui model edutainment berdasarkan hasil penelitian yang dilakukan sebanyak tiga kali di kelas X MIPA 4 SMA Negeri 6 Bandung. Berikut ini merupakan tabel hasil persentase perkembangan pemahaman kesejarahan siswa dari siklus I-III.

Tabel 2. Perolehan Skor Pemahaman Kesejarahaan Siswa dengan Menggunakan Model Edutainment Pada Tindakan I-IV

\begin{tabular}{cccccc}
\hline \multirow{2}{*}{ No. } & Kelompok & Tindakan I & \multicolumn{2}{c}{ Perolehan Skor } \\
& Tindakan II & Tindakan III & Tindakan IV \\
\hline 1. & 1 & 4 & 5 & 8 & 8 \\
2. & 2 & 3 & 5 & 8 & 8 \\
3. & 3 & 4 & 4 & 8 & 8 \\
4. & 4 & 4 & 6 & 8 & 8 \\
\hline
\end{tabular}


SHEs: Conference Series 3 (2) (2020) 193- 203

\begin{tabular}{|l|c|c|c|c|}
\hline Jumlah Skor & 15 & 20 & 36 & 36 \\
\hline Jumlah Skor Max & \multicolumn{4}{|c|}{36} \\
\hline Nilai Rata-Rata & $41,6 \%$ & $55,5 \%$ & $100 \%$ & $100 \%$ \\
\hline
\end{tabular}

Jumlah Skor Max = Jumlah Kelompok x Skor Maksimal Indikator

Nilai Rata-Rata $=$ Jumlah Skor x 100

\section{Jumlah Skor Maksimal}

Seperti yang ditunjukkan pada tabel di atas bahwa hasil dari observasi lapangan menunjukkan pemahaman kesejarahan siswa mengalami peningkatan setelah di terapkannya model edutainment dalam pembelajaran sejarah di kelas. Jumlah perolehan rata-rata tindakan I adalah $41,6 \%$. Kemudian pada tindakan II, perolehan ratarata adalah $55,5 \%$. Sedangkan pada tindakan III dan IV, perolehan rata-rata adalah $100 \%$.

Kenaikan perolehan rata-rata data di atas mengindikasikan bahwa model edutianment dalam pembelajaran sejarah dapat mendorong siswa mencapai indikator pemahaman kesejarahan berupa, mampu mengidentifikasi sumber-sumber sejarah, merekonstruksi jalannya peristiwa sejarah, dan mampu menggambarkan peristiwa sejarah dengan bahasa sendiri. Pada tindakan III dapat dilihat mendapatkan hasil yang sempurna, hal ini dikarenakan siswa mulai terbiasa dalam membuat cerita sejarah pada setiap tindakan yang dilakukan. Peningkatan yang terjadi dari mulai tindakan I, II, III, dan IV menunjukkan bahwa memang penerapan model edutainment dalam pembelajaran sejarah dapat meningkatkan pemahaman kesejarahan siswa dengan cukup baik. Selanjutnya, untuk memperjelas data yang berada di tabel, berikut adalah grafik kenaikan pemahaman kesejarahan siswa kelas X MIPA 4 pada setiap tindakan:

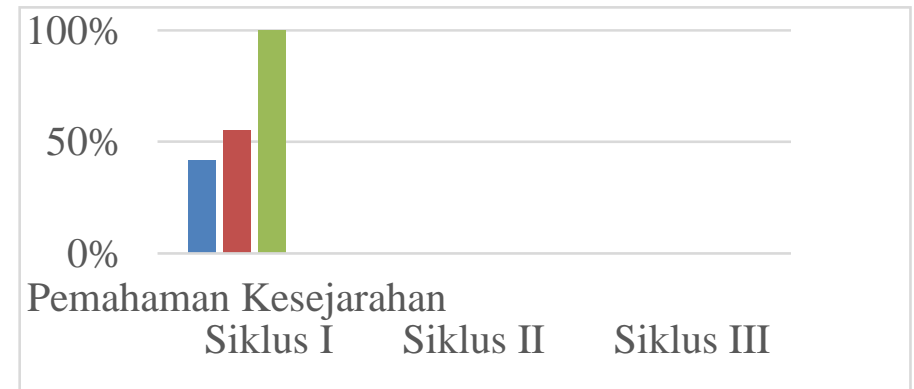

Gambar 1. Grafik Hasil Persentase Pemahaman Kesejarahan Siklus I-III

Grafik di atas menunjukkan bahwa penerapan model edutainment dari tindakan I sampai dengan tindakan IV berjalan dengan baik. Hal ini ditunjukkan dengan adanya peningkatan skor yang diperoleh berdasarkan tingkat ketercapaian siswa dalam kelompok pada setiap indikator dari penerapan model edutainment untuk meningkatkan pemahaman kesejarahan siswa. Dapat dikatakan bahwa model edutainment berhasil meningkatkan pemahaman kesejarahan siswa kelas X MIPA 4. Berikut tabel indikator pemahaman kesejarahan siswa di setiap tindakan:

Tabel 3. Hasil Indikator Historical Comprehension pada Siklus I-III

\begin{tabular}{|c|c|c|c|c|}
\hline \multirow{2}{*}{ No. } & \multirow{2}{*}{ Indikator Historical Comprehension } & \multicolumn{3}{|c|}{ Persentase Tindakan } \\
\cline { 3 - 5 } & $\begin{array}{c}\text { Siklus } \\
\text { I }\end{array}$ & $\begin{array}{c}\text { Siklus } \\
\text { II }\end{array}$ & Siklus III \\
\hline
\end{tabular}




\begin{tabular}{|c|c|c|c|c|c|}
\hline 1. & $\begin{array}{l}\text { Mampu } \\
\text { mengidentifikasi } \\
\text { sumber sejarah } \\
\text { seperti buku, } \\
\text { dokumen, atau } \\
\text { narasi sejarah } \\
\text { dan menilai } \\
\text { kredibilitasnya. }\end{array}$ & $\begin{array}{l}\text { Siswa mampu } \\
\text { mengumpulkan } \\
\text { sumber-sumber } \\
\text { sejarah. }\end{array}$ & $33,33 \%$ & $66,67 \%$ & $100 \%$ \\
\hline 2. & $\begin{array}{l}\text { Merekonstruksi } \\
\text { jalannya suatu } \\
\text { peristiwa } \\
\text { sejarah. }\end{array}$ & $\begin{array}{l}\text { Siswa: } \\
\text { a. Mampu } \\
\text { mengidentifikasi } \\
\text { tokoh yang terlibat } \\
\text { dalam peristiwa } \\
\text { sejarah. } \\
\text { b. Mampu } \\
\text { mengidentifikasi } \\
\text { sebab akibat } \\
\text { terjadinya suatu } \\
\text { peristiwa sejarah. } \\
\text { c. Mampu } \\
\text { mengidentifikasi } \\
\text { tempat terjadinya } \\
\text { peristiwa sejarah. } \\
\text { d. Mampu } \\
\text { mengidentifikasi } \\
\text { waktu terjadinya } \\
\text { peristiwa sejarah. }\end{array}$ & $58,33 \%$ & $50 \%$ & $100 \%$ \\
\hline 3. & \begin{tabular}{ll}
\multicolumn{2}{l}{ Memberikan } \\
pendapat atau \\
penilaian & \\
terhadap & suatu \\
peristiwa & \\
sejarah & yang \\
terjadi. & \\
\end{tabular} & $\begin{array}{l}\text { Mampu } \\
\text { menggambarkan } \\
\text { peristiwa masa lalu } \\
\text { dengan } \\
\text { menggunakan } \\
\text { bahasa sendiri. }\end{array}$ & $33 \%$ & $50 \%$ & $66,67 \%$ \\
\hline
\end{tabular}

Berdasarkan tabel di atas diperoleh gambaran bahwa pada indikator pemahaman kesejarahan siswa yang pertama, yaitu siswa mampu mengumpulkan sumber-sumber sejarah mengalami peningkatan dari siklus I hingga siklus III. Pada siklus I rata-rata nilai indikator tersebut sebesar 33,33\%. Kemudian mengalami peningkatan pada siklus II sebesar $66,67 \%$. Kemudian pada tindakan terakhir, yaitu siklus III mengalami peningkatan kembali menjadi $100 \%$. Tentunya peningkatan ini dipengaruhi oleh usaha peneliti untuk mengatasi kendala siswa yang cenderung kurang maksimal dalam mengumpulkan sumber-sumber sejarah. Peneliti menyediakan buku yang bersangkutan dengan materi juga memerintahkan siswa untuk meminjam buku ke perpustakaan serta menilai sumber-sumber internet yang ditemukan dan digunakan oleh siswa apakah dapat dipercaya atau tidak.

Selanjutnya, pada indikator kedua, yaitu mengidentifikasi nama tokoh, proses sebab akibat, tempat, dan waktu terjadinya peristiwa sejarah mengalami penurunan pada siklus II. Siklus I diperoleh hasil rata-rata nilai indikator tersebut sebesar 58,33\%. Sedangkan pada siklus II mengalami penurunan hasil rata-rata nilai indikator menjadi $50 \%$. Tetapi, pada siklus III mengalami peningkatan kembali secara maksimal dengan rata-rata nilai indikator sebesar $100 \%$. Bila dilihat dari setiap indikator, indikator kedua ini yang hanya mengalami penuruan pada siklus II sebesar $8,33 \%$. Memang, indikator 
ini menjadi indikator yang terkadang terlewatkan oleh siswa, seperti tidak mencantumkan waktu terjadinya peristiwa sejarah atau proses sebab akibat terjadinya peristiwa sejarah tidak sesuai dengan fakta yang ada. Penuruan ini pun disebabkan peneliti yang kurang memperhatikan proses pembuatan cerita sejarah oleh siswa secara berkelompok. Tetapi pada tindakan terakhir mengalami peningkatan yang maksimal.

Pada indikator terakhir, yakni indikator mampu menggambarkan peristiwa sejarah dengan menggunakan bahasa sendiri, mengalami peningkatan dari siklus I hingga siklus III, walaupun pada siklus III tidak mengalami peningkatan yang maksimal seperti indikator 1 dan 2. Pada siklus I diperoleh rata-rata nilai indikator sebesar $33 \%$. Sedangkan pada siklus II diperoleh rata-rata nilai indikator sebesar $50 \%$. siklus III diperoleh rata-rata nilai indikator sebesar $66,67 \%$. Dilihat dari perbandingan indikator 1 , 2 , dan 3, indikator 3 ini yang tidak mencapai hasil maksimal pada tindakan terakhir. Hal ini memang disebabkan karena apabila siswa ingin mahir dalam membuat cerita sejarah dengan bahasa sendiri perlu adanya latihan berkala secara terus menerus. Meskipun tidak mencapai hasil yang maksimal, namun setiap tindakan selalu mengalami kenaikan. Untuk memperjelas data perolehan nilai rata-rata dari setiap indikator, berikut ini grafik indikator pemahaman kesejarahan siswa pada setiap tindakan:

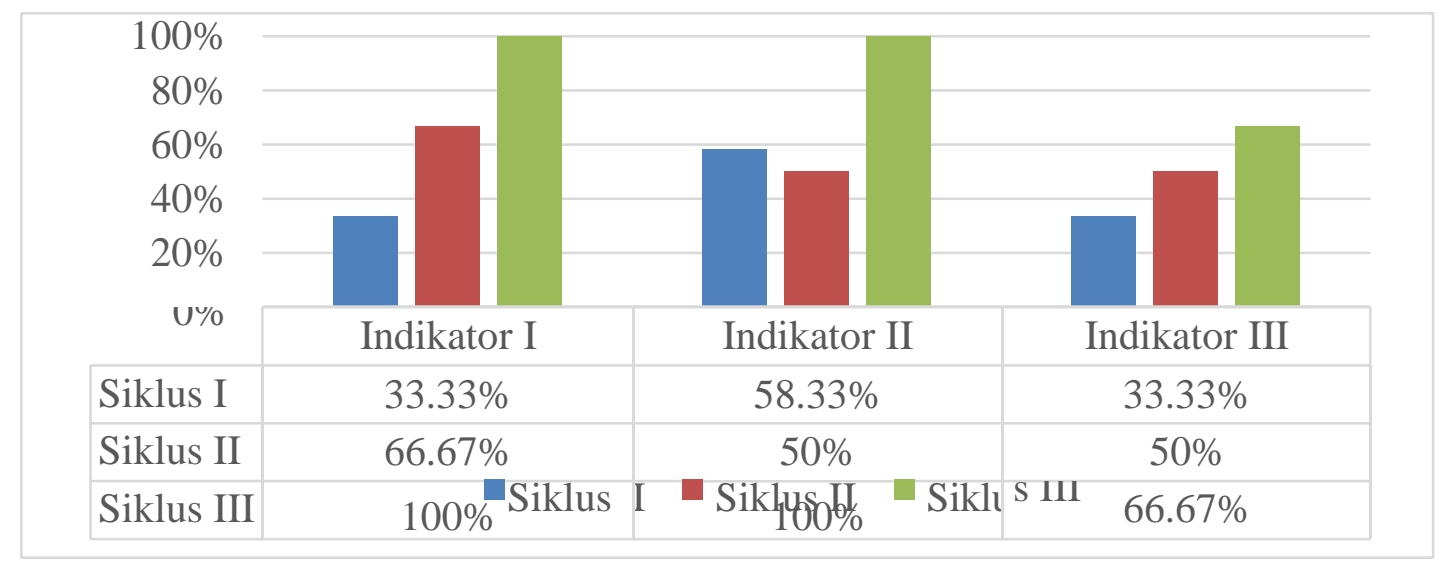

Gambar 2. Hasil Indikator Pemahaman Kesejarahan Siklus I-III

Berdasarkan grafik di atas menunjukkan bahwa penerapan model edutainment dari tindakan I hingga tindakan IV berjalan dengan baik meskipun terdapat penurunan pada indikator 2. Tetapi, mengalami peningkatan kembali secara maksimal pada tindakan III dan IV. Hal ini menunjukkan adanya peningkatan nilai rata-rata yang diperoleh siswa pada setiap indikator dari penerapan model edutainment untuk meningkatkan pemahaman kesejarahan siswa dalam pembelajaran sejarah. Dapat dikatakan pula bahwa model edutainment berhasil meningkatkan pemahaman kesejarahan siswa di kelas X MIPA 4.

Peningkatan pemahaman kesejarahan siswa melalui model edutainment ini tentunya dipengaruhi oleh berbagai faktor juga. Modal utama dari keberhasilan penerapan model edutainment ini adalah rasa senang/gembira siswa saat belajar. Hal ini tergambarkan pada saat melakukan wawancara dengan siswa dimana mereka mengungkapkan bahwa pembelajaran dengan model edutainment juga metode cerita sejarah ini membuat mereka merasa tidak sedang belajar juga mereka merasa gembira ketika membuat cerita sejarah yang telah dibuat dan dibacakan di depan kelas. Hal ini berarti menunjukkan bahwa model edutainment terlaksana dengan baik, seperti yang 
dikemukakan oleh Hamid (2013, hlm. 19-20) bahwa model edutainment adalah suatu cara untuk membuat proses pendidikan dan pengajaran bisa menjadi begitu menyenangkan, sehingga para siswa dapat dengan mudah menangkap esensi dari pembelajaran itu sendiri, tanpa merasa bahwa mereka tengah belajar.

Faktor selanjutnya ialah pemilihan materi yang tepat dengan menggunakan model edutainment. Sebenarnya, materi yang dipakai memang sangat banyak dan membingungkan bagi sebagian siswa, dimana salah satunya ialah materi mengenai Kerajaan-Kerajaan Hindu Buddha di Indonesia. Namun, karena penerapan model edutainment menggunakan if history yang dikolaborasikan dengan cerita sejarah, dalam wawancara setelah menerapkan pembelajaran ini siswa mengungkapkan mereka jadi lebih mengerti materi yang didapat tanpa merasa kesulitan untuk memahami materi yang disampaikan. Mereka merasa seperti sedang tidak belajar, tetapi seperti sedang bercertia dongeng kisah mereka sendiri yang terlibat pada suatu peristiwa sejarah, padahal mereka sedang mempelajari materi yang dibungkus dalam cerita sejarah. Tentunya pemilihan materi ini didasarkan pada pendapat yang disampaikan oleh Hamruni (dalam Pangastuti, 2014, hlm. 63) bahwa edutainment harus memperhatikan beberapa aspek, diantaranya menarik perhatian siswa dan menyajikan materi yang relevan. Pemilihan materi yang tepat dalam penerapan model edutainment dengan metode cerita sejarah membuat siswa tertarik dalam mempelajari materi tersebut. Siswa dibawa ke dalam suasana yang menyenangkan sehingga pembelajaran pun tidak merasa bosan.

Naiknya pemahaman kesejarahan siswa ini sesuai dengan yang telah guru mitra sampaikan saat melakukan wawancara setelah peneliti melakukan pembelajaran sejarah berbasis model edutainment menggunakan if history. Guru mitra menyampaikan bahwa penelitian ini telah berhasil meningkatkan pemahaman kesejarahan siswa dengan melihat dari perolehan nilai hasil UAS yang didapatkan siswa kelas X MIPA 4. Kebanyakan dari para siswa memperoleh nilai di atas standar kelulusan, hanya sedikit yang memperoleh hasil di bawah standar kelulusan.

\section{SIMPULAN}

Berdasarkan hasil penelitian tindakan kelas yang dilakukan di kelas X MIPA 4 SMA Negeri 6 Bandung, maka dapat ditarik kesimpulan bahwa terjadi peningkatan dalam pemahaman kesejarah siswa. Hal ini dapat terlihat dari beberapa perubahan yang terjadi pada siswa, yakni: 1) Siswa sudah mampu mengumpulkan, memilah, dan memilih sumber-sumber apa saja yang dapat digunakan seperti buku dan sumber internet yang dapat dipercaya untuk digunakan dalam materi pembelajaran; 2) Siswa sudah mampu merekonstruksi jalannya suatu peristiwa sejarah baik dari segi tokoh, waktu, tempat, hingga sebab akibat terjadinya suatu peristiwa sejarah yang terjadi di masa lampau; 3) Siswa sudah mampu untuk menyampaikan dan menilai suatu peristiwa sejarah dengan menggunakan bahasa yang mereka gunakan sendiri dengan memposisikan dirinya seolah-olah terlibat dalam suatu peristiwa sejarah.

Berdasarkan hasil temuan terdapat beberapa rekomendasi yang ingin peneliti sampaikan kepada berbagai pihak yang berhubungan dengan penelitian ini. Rekomendasi tersebut diharapkan dapat membuat pembelajaran sejarah lebih baik dan lebih efektif sebagai upaya dalam memaksimalkan pencapaian tujuan pembelajaran sejarah yang dilaksanakan sekolah. Terdapat hal-hal yang masih harus diperhatikan kembali oleh pihak-pihak terkait dan peneliti selanjutnya yang tertarik untuk melakukan penelitian dengan penerapan model edutainment.

Penelitian ini bukan merupakan hasil yang sempurna, hal ini disebabkan oleh keterbatasan peneliti dalam mendeskripsikan dan membahas permasalahan dalam penelitian. Oleh karena itu perlu adanya penelitian lebih lanjut mengenai model 
edutainment yang dapat dijadikan acuan untuk guru, sekolah, maupun calon guru yang hendak melakukan kegiatan penelitian ataupun yang mengharapkan meningkatkan pemahaman kesejarahan siswa khususnya dalam pembelajaran sejarah.

\section{DAFTAR PUSTAKA}

Fanani, A. (2010). Ice Breaking dalam Proses Belajar Mengajar. Jurnal Buana Pendidikan. 6(11): 67-70

Hamid, S. (2013). Metode Edutainment. Yogyakarta: DIVA Press.

Hidayanti, E. N. \& Djumali. (2016). Penerapan Metode Edutainment Humanizing The Classroom Dalam Bentuk Moving Class Terhadap Hasil Belajar. Jurnal Pendidikan IImu Sosial. 26(1): 11-19

Ismaun. (2005). Pengantar Belajar Sejarah sebagai IImu dan Wahana Pendidikan. Bandung: Historia Utama Press

Kumalasari, R. (2016). Mengembangkan Historical Comprehension Siswa dalam Pembelajaran Sejarah melalui Penerapan Fenomenografi (Penelitian Tindakan Kelas di Kelas X IIS 2 SMA Negeri 4 Bandung). (Skripsi). Bandung: Universitas Pendidikan Indonesia

Ma'mur, T. (2008). Upaya meningkatkan Kualitas Pembelajaran Sejarah Melalaui Historical Thingking. Bandung: Jurusan Pendidika Sejarah FPIPS UPI.

Pangastuti, R. (2014) .Edutainment PAUD. Yogyakarta: Pustaka Belajar

Setyorini. E. (2018). Penerapan Discovery Learning Untuk Meningkatkan Historical Comprehension Dan Hasil Belajar Peserta Didik Mata Pelajaran Sejarah Kelas XI IPS 3 di SMAN Jenggawah Tahun Ajaran 2017/2018. (Skripsi)

Supriatna, N. (2007). Konstruksi Pembelajaran Sejarah Kritis. Bandung: Historia Utama Press 